\title{
Dygðir, siðferði og siðferðisproski: Að nota Íslendingasögur til mannkostamenntunar
}

\author{
Róbert Jack
}
Abstract
- Um höfundinn
About the author
- Heimildir

Ein leið til að sinna mannkostamenntun er að lesa bókmenntir og greina og ræða mannkosti í peim með nemendum. Í pessari grein er fjallað um forsendur pess að nota Íslendingasögur til mannkostamenntunar með nemendum á unglingsaldri. Rætt er um mikilvægi dygða fyrir mannkostamenntun, áherslu hennar á siðferðilegar dygðir og almenn tengsl dygða og siðferðis. Dá er fjallað um pær aðstæður í bókmenntum par sem dygðir (eða lestir) birtast en pær eru hér kallaðar dygðaaðstæður. Rökstutt er að ekki sé erfitt að finna slíkar aðstæður í Íslendingasögum. Í ljósi tengslanna á milli dygða og siðferðis er jafnframt fjallað um siðferði Íslendingasagna og hvernig fræðileg umræða um pað efni getur haft áhrif á mannkostamenntun. Auk pess er velt upp peirri spurningu hvort pað siðferði sem viðgekkst á tímum Íslendingasagnanna sé sama siðferðið og er viðtekið nú til dags. Stigskipt proskalíkan Gilligan er notað til að staðsetja siðferðilegan veruleika Íslendingasagna gagnvart nútímasiðferði. Мeð hjálp proskalíkansins má einnig bregðast betur við peirri spurningu hvort hægt sé að nota sögu par sem siðferði persóna er ef til vill ekki til fyrirmyndar til að efla siðferði nemenda. Með pví að nota proskalíkanið er samtímis hægt að skoða einkenni peirrar siðferðilegu hugsunar sem stefna má að í mannkostamenntun með unglingum.

Efnisorð: mannkostamenntun, bókmenntakennsla, Íslendingasögur, dygðir, siðferðisproski, siðferði.

Eins og rakið er í grein Atla Harðarsonar, Ólafs Páls Jónssonar, Róberts Jack, Póru Bjargar Sigurðardóttur og Sigrúnar Sifjar Jóelsdóttur (2018) í pessu sérhefti Netlu hefur verið nokkur áhersla á að styrkja siðferðilega menntun í skólum á síðari árum og er mannkostamenntun liður í pví. Markmið greinarinnar er að gera grein fyrir helstu forsendum mannkostamenntunar, að minnsta kosti eins og hún birtist í bókmenntakennslu, og skýra hvernig beita má peirri nálgun á Íslendingasögur sérstaklega. Í pví sambandi er fjallað um áherslu mannkostamenntunar á dygðir, tengsl dygða og siðferðis, dygðaððtæður í bókmenntum, siðferði Íslendingasagna og hvernig pað er frábrugðið siðferði okkar í dag og loks eru nokkur orð sögð um pá siðferðilegu hugsun sem getur verið markmið mannkostamenntunar með unglingum.

Tilurð pessarar greinar tengist rannsókn á bókmenntakennslu með áherslu á siðferðilegar dygðir sem fram fór við prjá grunnskóla haustið 2017. Rannsóknin byggðist á hugmyndum mannkostamenntunar og fólst 1 a a lesa bókmenntir í móðurmálskennslu með sérstakri áherslu á dygðir. Sambærileg rannsókn hafði áđur verið gerð við Jubilee-miðstöðina við Háskólann í Birmingham og var tekið mið af reynslunni paðan við framkvæmd rannsóknarinnar (sbr. The Jubilee Centre for Character \& Virtues, 2014). Grunnpættir íslensku rannsóknarinnar eru raktir í 
grein Atla Harðarsonar o.fl. (2018) í pessu sérhefti Netlu. Fjallað er um aðra anga rannsóknarinnar í greinum Atla Harðarsonar (2018), Ólafs Páls Jónsson (2018) og Póru Bjargar Sigurðardóttur (2018), en hér verður einungis fjallað um pau atriði rannsóknarinnar sem pykja skipta máli fyrir umræðuna í pessari grein.

एó að íslensku rannsókninni hafi mjög svipað til peirrar ensku er rétt að nefna hér tvennt sem var með öðru sniði en pað tengist aldri nemenda og notkun lesefnis. Í rannsókn Jubileemiðstöðvarinnar voru nemendur 9 til 11 ára en í peirri íslensku voru peir 14 og 15 ára. Dví er gert ráð fyrir að pað sem hér er sagt henti einkum fyrir pann aldurshóp og jafnvel yngstu bekki framhaldsskóla. Lesefnið sem notað var í ensku rannsókninni var mikið styttar endursagnir á klassískum ritum. Dessar endursagnir miðuðu fyrst og fremst að pví að draga fram dygðirnar í sögunum. Hér á landi var ákveðið að lesa Laxdælu sögu með nemendum og skoða pær dygðir sem par er að finna. Dó að notuð hafi verið endursögn á sögunni (Laxdalu saga, 2017) er sú endursögn bæði lengri en ensku endursagnirnar og ekki sérstaklega miðuð að pví að par komi fram pær dygðir sem finna má í sögunni óstyttri.

Fyrir kennsluna var einnig útbúið námsefni og kennsluleiðbeiningar með Laxdœlu sem nú má nálgast á vef Menntamálastofnunar (Róbert Jack, 2018b). Af peirri ástæðu að Laxdæelu var notuð í verkefninu eru dæmin sem hér eru nefnd í Íslendingasögum úr Laxdælu pó að gert sé rád fyrir að rökræðan eigi almennt við um Íslendingasögur. Drátt fyrir að endursögn á Laxdœlu hafi verið notuð í rannsóknarverkefninu er í pessari grein gengið út frá sögunni óstyttri.

Greinin skiptist í prjá kafla. Í peim fyrsta er fjallað um áherslu mannkostamenntunar á dygðir og tengsl dygða og siðferðis. Í öðrum kaflanum er rætt um dygðaaðstæður og helstu einkenni pess siðferðilega veruleika sem finna má í Íslendingasögum. Í priðja kaflanum er stigskipt proskalíkan Gilligan notað til að gera betri grein fyrir pví hvernig siðferði Íslendingasagna er frábrugðið siðferði okkar í dag og jafnframt til að varpa ljósi á pá siðferðilegu hugsun sem hafa má sem markmið fyrir mannkostamenntunina.

\section{Dygðir í mannkostamenntun}

Sú tegund mannkostamenntunar (e. character education) sem hér er gengið út frá sækir grunnhugmyndir sínar til umfjöllunar Aristótelesar um farsældina (Laxdæelu) eins og hún er túlkuð af Jubilee-mönnum, ${ }^{1}$ ekki síst Kristjáni Kristjánssyni (2015). Til að einfalda orðræðuna aðeins má segja að peir mannkostir sem hér um ræðir séu dygðir (Kristján Kristjánsson, 2002, bls. 10; sbr. Vilhjálm Árnason, 1985, bls. 33). Мeð öðrum orðum er mannkostamenntun pví fyrst og fremst dygðamenntun sem felst í pví að efla dygðir nemenda frekar en lesti, sem er hið gagnstæða, en dygðir eru einmitt grundvallaratriði í farsældarkenningu Aristótelesar.

Aristóteles leit svo á að farsæld (Laxdæelu) væri markmið mannlífsins og að dygðir væru nauðsynleg skilyrði farsældar og pað sem meira er pá fælist beinlínis farsæld í pví að vera dygðugur. Með öðrum orðum leiða dygðir ekki einungis til farsældar heldur eru pær pað sem ásamt fleiru skapar farsældina. Aristóteles leit að vísu ekki svo á að nægilegt væri að hafa til að bera dygðir til að vera fyllilega farsæll heldur skipti par einnig máli gód heilsa, samfélagið sem maður býr í og ýmsar efnislegar forsendur (sbr. Kristján Kristjánsson, 2015, bls. 25). Án dygða verður samt enginn farsæll og pví er nauðsynlegt að proska pær.

Önnur og óneitanlega nákvæmari pýðing á enska heitinu character education er skapgerðarmenntun. Skapgerðin skiptir máli fyrir dygðamenntun pví að litið er svo á að hún sé sá hluti persónuleikans par sem dygðirnar búi (Kristján Kristjánsson, 2010, bls. 27). Ekki er hér ástæða til að gera fyllilega grein fyrir skapgerðinni og stöðu hennar innan sálarlífsins. Samt er rétt að nefna pað einkenni skapgerðarinnar að geta brugðist við rökum og áeggjan og tekið pannig framförum. Með pessu móti getur kennsla proskað skapgerðina og hjálpað einstaklingum pannig að taka framförum í dygð en pað hlýtur að skipta höfuðmáli fyrir mannkostamenntun að pað sé mögulegt.

Í greininni eru peir kallaðir ,Jubilee-menn“ sem starfað hafa hjá Jubilee-miðstöðinni við Háskólann í Birmingham og hafa haldið fram mjög ápekkri hugmynd um mannkostamenntun. Aðgengilega samantekt á hugmyndum peirra er til að mynda að finna í bókinni Teaching character and virtue in schools (Arthur, Kristjánsson, Harrison, Sanderse og Wright, 2017). Pað vill svo til að petta eru allt karlmenn. 
Hvað má pá segja að einkenni sérstaklega pá tegund mannkostamenntunar sem hér er stuðst við? Til að svara pví að einhverju leyti má nefna helstu gagnrýni hennar á sumar aðrar nálganir á mannkostamenntun sem reyndar felur í sér vissa gagnrýni á skólakerfið. Inntak gagnrýninnar snýst um að vestræn skólakerfi hafi víða próast óeðlilega mikið í átt til pess sem má kenna við tæknihyggju eða verkhyggju (e. instrumentalism) (sbr. Morris, 2015). Par er áherslan fyrst og fremst á mælanleg ytri markmið. Detta leiði til ofuráherslu á stöðluð próf og nákvæm hæfniviðmið en vanrækslu á heildrænum proska manneskjunnar sem veru sem leita parf að merkingu í lífi sínu og skilja sinn félagslega og efnislega veruleika. Dessi verklega nálgun hefur einnig alið af sér verklega nálgun í mannkostamenntun sem leggur fyrst og fremst áherslu á pröngan hóp dygða sem kallaðar hafa verið framkvæmdadygðir og snúast ekki síst um að ná sem bestum árangri í námi og á vinnumarkaði (sbr. Kristján Kristjánsson, 2015). Í pví sambandi má nefna dygđir eins og prautseigju og sjálfstraust.

Í sjálfu sér er ekki ástæða til að gera athugasemd við pað að pessar dygðir séu kenndar en gagnrýnin beinist fyrst og fremst að tvennu varðandi pessa verklegu nálgun. Annars vegar sé hún of pröng, p.e. að of fáar dygðir séu teknar með, og siðferðilegar dygðir séu sérstaklega vanræktar. Hins vegar sé fyrst og fremst lögð áhersla á dygðir sem tæki til að ná árangri frekar en að pær séu sjálfar hlut af almennri farsæld. Eins og áđur segir lítur Aristóteles svo á að dygðirnar séu ekki einungis tæki til að ná öðrum markmiðum heldur hluti af farsældinni sjálfri og hann talar einnig um mikilvægi siðferðilegra dygða. Í pessari grein er tekið undir með Jubilee-mönnum pegar peir segjast vilja víkka markmið menntunarinnar pannig að pað nái ekki einungis til pess að ná tilteknum árangri í námi og á vinnumarkaði heldur fjalli einnig um að lifa farsælu lífi.

Varðandi innihald dygðanna sjálfra eru pær með ýmsu móti og má flokka pær á ólíka vegu (sbr. McLaughlin og Halstead, 1999, bls. 134) en Jubilee-menn hafa skipt peim í fjóra flokka. Deir tala um siðferðilegar dygðir, borgaralegar dygðir, framkvæmdadygðir og vitsmunalegar dygðir (The Jubilee Centre for Character \& Virtues, 2017, bls. 5; Kristján Kristjánsson, 2015, bls. 17). Dæmi um siðferðilegar dygðir eru heiðarleiki, réttlæti og auðmýkt. Djónusta og samfélagsleg vitund eru dæmi um borgaralegar dygðir. Prautseigja, leiðtogahæfni og sjálfstraust teljast til framkvæmdadygða. Og loks eru forvitni, gagnrýnin hugsun og einbeitingarfærni dæmi um vitsmunalegar dygðir. Sá sem ætlar sér að verða fyllilega farsæll parf pá að öðlast allar tegundir af dygðum. Að pví sögðu er erfitt að hugsa sér að hægt sé að setja saman endanlegan lista af dygðum sem eigi að henta öllum. Eðlilegra er að líta pannig á að pær dygðir sem purfi til að proskast séu ¡ð minnsta kosti að sumu leyti háðar bví félagslega og efnislega samhengi sem einstaklingurinn býr við. Par geta til að mynda fjölskylduhagir, starfsvettvangur og búseta skipt máli. Um leið er erfitt að ímynda sér að hægt sé að vera fyllilega farsæll með pví að einbeita sér alfarið að pröngum hópi dygða.

Án pess að hér verði sett fram heildstæð úttekt á pessari flokkun Jubilee-manna er ekki úr vegi að nefna skilning peirra á siðferðilegum dygðum. Detta er mikilvægt hér pví að peir leggja einmitt sérstaka áherslu á siðferðilegar dygðir og mikilvægi pess að vanrækja pær ekki. Almennur skilningur á hinu siðferðilega sviði virðist vera sá að pað snúist umfram allt um samskipti fólks. Skilningur Jubilee-manna á siðferðilegum dygðum er hins vegar víðari. Pannig líta peir ekki svo á að siðferði snúist eingöngu um samskipti við aðra heldur feli pað einnig í sér pætti sem snúi fyrst og fremst að einstaklingnum sjálfum (Arthur, Kristjánsson, Harrison, Sanderse og Wright, 2017, bls. 60). Pannig líta peir til dæmis svo á að hugrekki sé siðferðileg dygð pó að hún einskorðist ekki við samskipti við aðra (The Jubilee Centre for Character \& Virtues, 2017, bls. 5; Sanderse, 2015, bls. 383; Arthur o.fl., 2017, bls. 60). Til að mynda er hægt að vera hugrakkur í vondu veðri án pess að pað snerti sérstaklega aðra manneskju. Dessi víði skilningur Jubilee-manna á hinu siðferðilega sviði helgast af pví hvernig Aristóteles skildi hugtakið (sbr. Sanderse, 2012, bls. 78-79).

Ég mun hvorki fara út í pá umræðu hér hvernig Aristóteles hugsaði nákvæmlega hið siðferðilega svið né mun ég rökstyðja pá skoðun mína að óparfi sé að fylgja hugmynd Aristótelesar að pessu leyti nema með pví að vísa í pað sem pegar hefur verið sagt um almennan skilning á hinu siðferðilega sviði. Ég tel að pað sé heppilegra að fylgja viðtekinni hugtakanotkun á okkar 
tímum hvað petta varðar en skilningi Aristótelesar. Eftir stendur pá pað hverju petta skipti fyrir mannkostamenntun. Jubilee-menn virðast leggja sérstaka áherslu á siðferðilegar dygðir vegna pess að pær hafi verið vanræktar í skólakerfinu. En hverju breytir pessi víði skilningur peirra?

Hugsanlega mætti líta svo á að með pessum skilningi á siðferði vildu peir lauma til að mynda framkvæmdadygðum inn á hið siðferðilega svið. Með pví að leggja áherslu á siðferðilegar dygðir töluðu peir pví eins og áherslan væri á dygðir sem snerust um hæfileika okkar til að aðhafast á hinu siðferðilega samskiptasviði tilverunnar en í raun næðu dygðirnar sem peir vildu proska til fleiri sviða veruleikans.

Ef nánar er skoðað virðist pessi gagnrýni pó fyrst og fremst snúast um hugtakanotkun. Ef pað er gefið að almenn farsæld krefjist pess að einstaklingar proski með sér dygðir á sem flestum sviðum hins mannlega lífs, eins og komið hefur fram, er ekki nóg að fjalla einvörðungu um siðferðilegar dygðir, pröngt skilgreint, heldur parf einnig að proska aðrar dygðir, eins og framkvæmdadygðir og vitsmunalegar dygðir. Hvernig flokkunin er skiptir pá varla höfuðmáli ef menntunin er sú sama. Eftir stendur pá að mannkostamenntun Jubilee-manna leggur sérstaklega áherslu á siðferðilegar dygðir par sem aðrar tegundir dygða fá pó að fljóta með enda byggist farsældin á dygðum sem lúta að öllum sviðum mannlífsins.

Аð pessu sögðu er í peirri umræðu sem hér fer fram meiri áhersla á siðferðilegar dygðir í samskiptaskilningnum en aðrar dygðir. Dað er varla tilviljun enda má segja að orðið „,dygð“ sé alla jafna skilið siðferðilegum skilningi. Í Íslenskri orðabók (2003, bls. 243) segir til að mynda að dygð sé „góður siðferðilegur eiginleiki“. Annað pað sem hér hefur verið kallað dygð, eins og sjálfstraust og gagnrýnin hugsun, er pá gjarnan kallað hæfileiki eða færni eða einfaldlega góður eiginleiki. Pannig er ekki úr vegi að segja að sterk tengsl séu á milli dygða almennt og siðferðis. Gera má pannig ráð fyrir pví að gott siðferði einkennist af góðum dygðum og jafnframt að par sem einstaklingar séu að jafnaði prýddir góðum dygðum sé siðferði jafnframt gott. Við kippum okkur pví ekki upp við að sumar dygðir séu strangt tiltekið ekki siðferðilegar enda stefna pær einnig að pví að skapa farsælt líf.

\section{Dygðaaðstæður og siðferði í Íslendingasögum}

Nú hefur verið fjallað um mikilvægi dygða fyrir mannkostamenntun og par sem umfjöllunarefni okkar er notkun Íslendingasagna í mannkostamenntun er eðlilegt að snúa sér að stöðu dygða í peim sögum. Degar stórt er spurt er oft fátt um svör en segja má að frekar lítið hafi verið fjallað fræðilega um dygðir sem slíkar í Íslendingasögum (sjá pó Róbert Jack, 2018a). Meiri fræðileg umræða hefur hins vegar farið fram um siðferði sagnanna almennt. Í pessum kafla mun ég gera tvennt. Fyrst skoða ég hvernig lesa má dygðir út úr Íslendingasögum en í pví skyni skoða ég sérstaklega svokallaðar dygðaaðstæður par sem dæmi verða tekin úr Laxdælu sögu. Pá verður gripið niður í hina fræðilegu umræðu um siðferði í Íslendingasögum pví pó að siðferðið spanni ekki allt litróf dygðanna gefur pað að minnsta kosti vísbendingu um stöðu siðferðilegra dygða, sem er mikilvægur hluti peirra dygða sem fjallað er um í mannkostamenntun, eins og fram hefur komið. Dessari umræðu er ætlað að sýna okkur hvernig nálgast má dygðir í bókmenntum, par sem dæmi eru tekin úr Laxdælu, og að siðferði sé mikilvægur páttur í Íslendingasögum.

Víkjum pá að pví hvernig greina má tilvist dygða í Laxdœlu. Dað eru að minnsta kosti tvær leiðir til að lesa dygðir út úr bókmenntatexta eins og Laxdclu (sbr. Róbert Jack, 2018a). Annars vegar er stundum beinlínis talað um ákveðnar dygðir eða lesti í sögunni. Hins vegar má hugsa sér að pó að ekki séu orðaðar neinar dygðir eða lestir megi nota ákveðnar athafnir eða aðstæður sem sögupersónur eru í til að velta fyrir sér hvað sé dygðugt að gera og hvað ekki. Petta kýs ég að kalla dygðaaðstæður. Hér er pá um að ræða aðstæður sem kalla á pað að persóna taki afstöðu til pess hvað á að gera. Pessar aðstæður geta verið misjafnlega krefjandi, stundum er togstreitan mikil og stundum minni, en ávallt má velja að vera dygðugur eða ekki. Í bókmenntakennslu par sem áhersla er á dygðamenntun er lykilatriði að koma auga á pessar dygðaaðstæður í sögunni. 
Раð að finna dygðaaðstæður er iðulega mikilvægara en að fjalla um pá staði par sem dygðir eru beinlínis nefndar vegna pess að par er algengara að einfaldlega sé verið að gefa persónum einkunn, oftast án beins rökstuðnings. Slíkar umsagnir um persónur gefa nemendum pví ekki tækifæri til að íhuga dygðina með eins djúpum hætti og dygðaaðstæðurnar. Dæmi um staði í Laxdcelu par sem dygðir eru nefndar beint eru pegar Jórunn Bjarnardóttir er sögð vera „skörungur mikill í vitsmunum“ (kafli 9) og Ólafur pái Höskuldsson er sagður stórmannlegur sem ungbarn (kafli 13). Dessum lýsingum fylgja engar útskýringar og pær gefa pví lítið tilefni til pælinga um pað hvað felst í pessum dygðum. Sumir staðir par sem dygðir eru nefndar í Laxdalu gefa pó frekar tilefni til vangaveltna og getur par verið um dygðaaðstæður að ræða. Varðandi dygðamenntunina skiptir pá í raun ekki svo miklu hvort dygðin er nefnd í sögunni heldur hvort aðstæðum sé pannig lýst að nemendur geti velt pví fyrir sér hvort viðbrögð sögupersónunnar einkennist frekar af dygð eða lesti.

Dæmi um dygðaaðstæður í Laxdœelu er pegar Duríður Ólafsdóttir vænir eiginmann sinn Geirmund gný um að haga sér ódrengilega par sem hann ætlar að fara af landi án pess að taka dóttur sína með sér og án pess að skilja eftir fé (kafli 30). Hér er tækifæri til að ræða hegðun Geirmundar og skoða hvort staðhæfing Duríðar um ódrengskap eigi við rök að styðjast. Aðrar aðstæður sem nefna má eru hegðun Kjartans Ólafssonar pegar hann porir að keppa í sundi við ópekktan sundmann sem reynist vera Ólafur Tryggvason, konungur Noregs, og jafnframt pegar Kjartan hefur uppi stór orð um að láta konunginn ekki kúga sig til að taka kristni og segist meira að segja vilja freista pess að brenna hann inni (kafli 40). Í pessu sambandi nefnir höfundur Laxdœlu enga sérstaka dygð en hér getum við velt fyrir okkur hvort Kjartan sýni hugrekki eða jafnvel frekar fífldirfsku. Mörg fleiri dæmi af pessum toga eru rædd í grein minni Dygðirnar í Laxdœlu sögu (Róbert Jack, 2018a). Sú grein er nánari rökstuðningur fyrir tilvist dygðanna í Laxdæelu sérstaklega en telja má líklegt að fjalla megi um dygðir í öðrum Íslendingasögum með svipuðum hætti.

Nú, pegar leiddar hafa verið að pví líkur að ekki sé erfitt að finna aðstæður í Íslendingasögum par sem dygðir birtast, er rétt að velta fyrir sér inntaki pess siðferðis sem finna má í sögunum. Par er ef til vill eðlilegast að líta til fræðilegrar umræðu enda hefur nokkuð verið um petta fjallað. Af pví einu að um petta hafi verið skrifað má ráða að hægt er að verða einhvers vísari um siðferðilegan veruleika sagnanna. Dar á ég við að pó að siðferðileg umræða liggi par ekki á yfirborðinu gefi textinn ýmsar vísbendingar um pennan siðferðilega veruleika. Leiðandi spurning hér er hvað helst einkenni siðferði Íslendingasagna en angi af peirri umræðu er hvort gera megi ráð fyrir sjálfstæðri yfirvegun og ákvarðanatöku af hálfu persóna í sögunum.

Segja má að almennt samkomulag hafi ríkt um pað að siðferði Íslendingasagna einkennist fyrst og fremst af heiðri og sæmd pannig að persónur sagnanna stefni öðru fremur að pví að öðlast virðingu en forðast svívirðingu og skömm (sbr. Torfa H. Tulinius, 2001, bls. 57; Kristján Kristjánsson, 1998, bls. 409; Svavar Hrafn Svavarsson, 2009, bls. 248; van den Toorn, 1955, bls. 140; Frölich, 2000, bls. 51) en hér verður petta kallað sæmdarsiðferði. Ekki er ætlunin að rökstyðja mikilvægi sæmdarinnar í Íslendingasögum hér (Meulengracht Sørensen, 1995; Samdarmenn, 2001) en pó má nefnt eitt dæmi úr Laxdælu. Eftir að Kjartan hafði lokað fólkið á Laugum inni og komið í veg fyrir að pað kæmist á salernið í prjár næu kemur fram að Laugamönnum hafi pótt petta miklu meiri svívirðing en ef Kjartan hefði drepið fyrir beim einn eða tvo menn (kafli 47). Hér má sjá að jafnvel mannslíf skipta minna máli en sæmdin.

Í hinni fræðilegu umræðu má finna tvö ólík sjónarhorn (sbr. Kristján Kristjánsson, 1998, bls. 407) sem lita umræðu um dygðir persóna en fræðilegir höfundar hafa iðulega valið sér annað peirra frekar en hitt. Annars vegar er um að ræða pað sem kalla má sjónarhorn einstaklingsins og hins vegar sjónarhorn samfélagsins. Munurinn á sjónarhornunum í hinni siðferðilegu umræðu hverfist um pað hvort litið er svo á að uppsprettu siðferðilegra athafna sé að finna hjá einstaklingnum eða í samfélaginu. Samkvæmt fyrra sjónarhorninu virðist einstaklingurinn að miklu leyti frjáls til að velja pá leið sem hann fer en samkvæmt hinu síðara geta athafnir hans verið allt að pví sjálfkrafa viðbragð við pjóðfélagslegum aðstæðum (sbr. Steblin-Kamenskij, 1981, bls. 84). 
Sigurður Nordal (1942, bls. 188-189), sem líta má á sem fulltrúa fyrra viðhorfsins, lýsir sæmdarsiðferðinu pannig að sá hetjuskapur sem í pví felst sé eiginleiki hinnar einstöku hetju. Dygðina drengskap telur Sigurður vera sérstakt einkenni slíkrar hetju en hún einkennir traustan og hugrakkan einstakling (bls. 187) sem jafnframt er frjáls og fullvalda (bls. 195). Viðhorf Kristjáns Kristjánssonar (1998, bls. 407-408) til sagnanna er líka af pessari rót en hann kallar petta „viðhorf leikmannsins“ og telur að svona hafi fólk alla jafna skilið sögurnar.

Í fræðiumræðu síðustu áratuga fer pó mun meira fyrir samfélagssjónarhorninu og ýmsir hafa orðið til að halda pví fram (sbr. Torfa H. Tulinius, 2001, bls. 58; Meulengracht Sørensen, 1995, bls. 187). Vilhjálmur Árnason $(1985,1991)$ er pó sá sem einna helst hefur sett pað fram 1 heimspekilegum búningi (sjá einnig MacIntyre, 2007, bls. 121-130). Vilhjálmur (1985, bls. $29,32)$ orðar раð svo að petta viðhorf til sagnanna leggi áherslu á „samspil siðareglna og samfélagsgerðar" frekar en að líta svo á að siðferði byggist ,á einhverri óljósri sómatilfinningu fáeinna einstaklinga“. Vilhjálmur (1985, bls. 31) leggur áherslu á að samfélagið hafi ekki haft pær stofnanir sem nauðsynlegar eru til að halda uppi lögum og reglu en við slíkar aðstæður er pá helst hægt að treysta á ættartengsl til að fá réttlætinu framgengt. Dví má segja að drengskapur 1 framangreindum skilningi trausts og hugrekkis ættmenna sé afar mikilvægur bakhjarl fyrir hvern einstakling pví mikilvægt er að ættmennin séu fær um að standa við skyldu sína til að hefna ef að manni er vegið. Drengskapur er samkvæmt pessu sjónarhorni pá skilgetið afkvæmi samfélagsgerðarinnar frekar en einstaklingsbundinn eiginleiki. MacIntyre (2007, bls. 123) orðar petta pannig að „siðferði og samfélagsgerð [séu] í raun eitt og hið sama í hetjusamfélagi“.

Баð er ekki tilgangurinn með pví að ræða pessi tvö sjónarhorn að leysa úr pessu ágreiningsefni um hvar siðferðið eigi upptök sín, í einstaklingnum eða samfélaginu. Dó verður ekki annað séð en að rökin fyrir báđum sjónarhornum séu býsna góð og pví virðist sérkennilegt að áherslan hafi frekar verið á að rökstyðja annað og útiloka hitt en að viðurkenna einfaldlega að pau skipti bæði máli. Dess má pó geta að bæði fulltrúar peirra sem verja samfélagsviðhorfið (Vilhjálmur Árnason, 1991, bls. 167) og peirra sem leggja áherslu á einstaklingsviðhorfið (Sigurður Nordal, 1942, bls. 188; Kristján Kristjánsson, 1998, bls. 418) hafa viðurkennt að nokkuð sé til í hinu viðhorfinu. Dá hefur Frölich (2000, bls. 85) lagt áherslu á bæði pessi sjónarhorn en umfjöllun hennar snýst reyndar ekki fyrst og fremst um siðferði.

Í pessu samhengi skiptir pessi umræða fyrst og fremst máli fyrir dygðamenntun að pví leyti að erfitt er að sjá fyrir sér að einstaklingur, sem ekki getur velt möguleikum fyrir sér og tekið sjálfstæða ákvörðun, geti lært að proska með sér dygð. Ef öll áhersla er á samfélagssjónarhornið og persónur í Íslendingasögum yfirvega ekki „,rétt og rangt, gott og illt, heldur birtist [siðferðileg vitund] óbrotin í viðbrögðum manna við aðstæðum sínum hverju sinni“ (Vilhjálmur Árnason, 1985, bls. 34) er vandséð hvernig hægt er að eigna einstaklingnum siðferðilega umhugsun svo nokkru nemi (sbr. einnig Svavar Hrafn Svavarsson, 2009, bls. 252). Раð аð fylgja eingöngu samfélagssjónarhorninu skapar líka viss vandkvæði fyrir hugmyndina um dygðaaðstæður pví að forsenda peirrar hugmyndar er að einstaklingar geti valið um að breyta í samræmi við dygð eða löst. Að vísu gætum við sagt að dygðaаðstæður og valfrelsi væru einungis atriði sem við lesum inn í söguna frá okkar nútímalega sjónarhorni en prátt fyrir pað virðist eitthvað ófullnægjandi við að einblína á samfélagsviðhorfið. Hér verða nefnd fjögur atriði.

Hugmyndin um algeran skort á yfirvegun brýtur í fyrsta lagi í bága við viðhorf leikmannsins sem nefnt var áður en pað virðist vera hversdagsleg sýn okkar á atburði að persónur geti ávallt breytt með öðrum hætti en pær gera. Dessu tengt má í öðru lagi segja að pað skemmi nokkuð upplifun okkar af Íslendingasögum ef við getum ekki gert ráð fyrir pví að persónur hafi val. Fullkomlega vélrænt ákvarðanaferli er nefnilega ekki í takt við pá hversdagslegu mannlegu upplifun að á hverju augnabliki lífsins geti ávallt ýmislegt gerst par sem sérhver einstaklingur hafi ávallt ákveðið valfrelsi í stað pess að einungis eitthvað eitt geti átt sér stað. Í priðja lagi firrir hugmyndin um sjálfvirkar athafnir út frá samfélagsgerð persónur siðferðilegri ábyrgð á gjörðum sínum en pað virðist flestum óviðunandi. Í fjórða lagi verður erfitt að skilja hvernig persónur í 
Íslendingasögum í mjög svipaðri stöðu geta tekið mismunandi ákvarðanir. Dæmi um petta er pegar Unnur djúpúđga kemur til Íslands snemma í Laxdæelu (kafli 5) og leitar ásjár hjá bræðrum sínum. Fyrst leitar hún til Helga sem býður henni einungis að vera hjá sér við tíunda mann en með henni komu tuttugu. Dá leitar hún til Björns sem býður henni að vera með allt sitt lið. Hvernig skýrum við pennan mun á örlæti bræðranna í samfélagi par sem ekkert rými er fyrir siðferðilega umhugsun?

\section{Siðferðisproski}

Áður en vikið verður nánar að spurningunni um siðferðilega yfirvegun vil ég bera saman almennt siðferði í Íslendingasögum og á okkar tímum í dag. Petta er mikilvægt viðfangsefni fyrir dygðamenntun pví að ef siðferðið í sögunum er allt annað en hjá okkur í dag má velta fyrir sér hvort Íslendingasögur séu pá gagnlegar til að mennta nútímanemendur í dygð. Í pessari rannsókn verður vitaskuld engum nákvæmum mælikvörðum viðkomið en um petta má pó hafa almenn orð. Í fyrsta lagi má einfaldlega nefna nokkur dæmi úr Laxdœlu par sem framferði persóna virðist okkur framandi í dag. Fyrst má nefna pegar Höskuldur kaupir ambátt af Gilla hinum gerska (kafli 12). Dað er eftirtektarvert við pessa lýsingu að höfundur virðist á engan hátt láta í pað skína að pað sé nokkuð óeðlilegt við kaup og sölu á fólki. Hér virðist hreinlega um mjög eðlileg viðskipti að ræða á pessa tíma mælikvarða. Ef við beinum svo sjónum almennt að mannvígum pá eru vissulega ekki allir sáttir við pau í Íslendingasögunum en almennt umburðarlyndi gagnvart peim og pær réttlætingar sem teknar eru gildar á peim eru með allt öðrum hætti en gerist í dag. Nægir par að nefna pegar Eldgrímur er drepinn fyrir hrossapjófnað (kafli 37) og Kjartan Ólafsson er veginn vegna móðgana hans og yfirgangssemi (kafli 49). Dó að vissulega séu til einstaklingar á öllum tímum sem eru til alls líklegir virðast dæmi eins og pessi sýna okkur að pau siðferðilegu viðmið sem póttu eðlileg í Íslendingasögum pyki ekki eðlileg í dag.

Í öðru lagi virðist í fræðilegri umræðu almennt sammæli um að nokkur munur sé á siðferði okkar daga og pví siðferði sem var við lýði í veruleika Íslendingasagna og á ritunartíma peirra (sbr. Vilhjálm Árnason, 1985, bls. 22; Steblin-Kamenskij, 1981, bls. 77). Kristján Kristjánsson (1998) reynir að vísu að verja ákveðin líkindi með siðferði Íslendingasagna og nútímasiðferði en par virðist hann frekar beina sjónum að peirri undirliggjandi siðfræði sem ætla má að sé til staðar á hverjum tíma frekar en að velta fyrir sér hinum siðferðilega veruleika eins og hann blasir við og hér er til umræðu.

Við gerum sem sagt ráð fyrir að pað siðferði sem við finnum í Laxdœlu sé ekki pað siðferði sem við viljum að nemendur tileinki sér. Í pví samhengi er gagnlegt að staðsetja siðferðið í Laxdęu betur gagnvart okkar siðferði en pað má gera með pví að finna pví stað í proskalíkani Gilligan. Með pessu móti getum við betur skilið grunnforsendur sæmdarsiðferðisins og hvers vegna persónurnar í Laxdæelu ættu ekki endilega að vera fyrirmyndir okkar í siðferðilegri breytni í dag. Einnig getur proskalíkan hjálpað okkur að skilja hvert við eigum pá frekar að stefna, hvert við ættum frekar að beina nemendum en að líta á persónur Laxdalu sem fyrirmyndir. Að pessu loknu verður proskalíkanið notað til að svara spurningunni úr síðasta kafla um siðferðilega umhugsun persóna í Íslendingasögum.

Degar kemur að pví að velja proskalíkan er nærtækast að nýta sér líkan sem lýsir siðferðisproska. Dar koma helst til greina proskalíkön Kohlbergs og Gilligan sem segja má að eigi sér sameiginlegan uppruna. Jubilee-menn hafa reyndar gagnrýnt Kohlberg af ýmsum ástæðum (sbr. Sanderse, 2012) og pá hafa peir sjálfir gert atlögur að pví að setja saman proskalíkan sem byggt er á kenningu Aristótelesar (sbr. Sanderse, 2012, bls. 102-117, 2015; Arthur o.fl., 2017, bls. 62-67). Um petta vil ég segja tvennt. Annað er pað að hægt er að taka undir ýmislegt af peirri gagnrýni sem Jubilee-menn setja fram á Kohlberg. Hugmyndin í pessu samhengi er pó fyrst og fremst að nota proskastigin sem finna má í líkani Gilligan - og eiga sér reyndar samsvörun hjá Kohlberg - en hjá Jubilee-mönnum er ekki að sjá neina gagnrýni á proskastigin sjálf. Deir gera að vísu athugasemdir við pað hvernig Kohlberg telur að einstaklingur geti færst á milli stiga (Sanderse, 2012, bls. 
103-104) en pað er ekki gagnrýni á proskastigin sjálf. Hitt er pað að proskalíkan Jubilee-manna kann að hafa ýmislegt sér til ágætis en pað hefur samt sem áður ekki verið staðfest í sams konar rannsóknum og proskalíkan Kohlbergs og Gilligan.

Við petta má bæta að Kohlberg taldi að siðferðisproski snerist um réttlætið en Jubilee-menn hafa einmitt bent á að pað dugi ekki pví að siðferðisproski hljóti að snúast um meira en einungis pessa einu dygð (Arthur o.fl., 2017, bls. 59-60). Líkt og Jubilee-menn gagnrýndi Gilligan (1993) Kohlberg einmitt fyrir of prönga nálgun á siðferðisproska. Hún taldi nálgun hans vera of karllæga en niðurstöður hennar sýndu að siðferðisproski kvenna hverfist frekar um umhyggju en réttlæti. Rannsóknir hennar staðfestu samt sem áður að nota má sömu prjú proskastigin til að lýsa umhyggjusiðferðinu og Kohlberg notaði til að lýsa hinni karllægu mynd siðferðisproska. Við petta má bæta að Kohlberg byggði líkan sitt á proskalíkani Piaget um vitsmunaproska (sbr. Gilligan, 1993, bls. 72-74) en par eru pá sömu proskastigin notuð til að túlka enn annað innihald. Dví verður ekki annað séð en að pað stigskipta proskalíkan sem Gilligan lýsir megi vel nota sem almennt viðmið um siðferðisproska eins og hér verður gert.

Ken Wilber (2006, bls. 11-12) hefur endursagt proskalíkan Gilligan (1993, bls. 73-74) með einföldum og skýrum hætti. Dar útskýrir hann hvert proskastig fyrir sig með pví að segja til um раð hvaða persónur einstaklingur á viðkomandi proskastigi taki með í siðferðilega útreikninga sína. Orða má pað pannig að hin siðferðilega nálgun byggist á pví að spyrja sig hver skipti máli við ákvarðanatöku. Er bað bara ég sem skipti máli? Erum pað við hérna sem ég geng út frá? Eða hugsa ég um okkur öll hvar sem við búum pegar ég tek ákvarðanir? Fyrsta stigið byggist sem sagt á pví að ég hugsa fyrst og síðast um sjálfan mig. Annað stigið gengur út frá okkur í fjölskyldunni, okkur sem búum hér á pessum stað eða einhverjum afmörkuðum hópi sem ég samsama mig með. Priðja stigið felst svo í pví að ég tek allar manneskjur með í reikninginn, hvar sem pær búa og hvernig sem pær líta út. Kannski mætti kenna stigin við einstaklingshyggju, fjölskylduhyggju og mannhyggju. Aukinn proski felst pá í pví að víkka út svið umhyggjunnar, réttlætisins, örlætisins eða hverrar peirrar dygðar sem kemur við sögu.

Ef við víkjum pá að persónum í Laxdalu með petta líkan að vopni virðast sumar peirra vera eigingjarnar pannig að pær framkvæmi hluti fyrst og fremst með eigin hag í huga og ómaki sig sjaldan fyrir aðra. Persónur af pessum toga eru Geirmundur gnýr og Porleikur Höskuldsson. Um pær má segja að pær njóti alla jafna ekki mikillar virðingar í sögunni, hvorki hjá öðrum persónum né er hægt að segja að höfundur Laxdæelu gefi peim góða einkunn. Að vísu er sagt að Geirmundur sé ríkur og mikill víkingur og stórlátur en hann er jafnframt sagður ódældarmaður, ópýður og ódrengilegur (kaflar 29 og 30). Porleiki er heldur ekki alls varnað að upplagi, hann er meðal annars sagður sterkur og myndarlegur, en svo virðist sem skuggahliðarnar yfirgnæfi hinar. Porleikur er sagður fálátur, ópýður, enginn jafnaðarmaður að skaplyndi enda stendur hann í illdeilum við ættmenn sína (kaflar 9, 20, 26 og 37). Jafnframt eru Geirmundur og Dorleikur jaðarpersónur í sögunni og aðalpersónur hennar virðast með öðru sniði. Dví virðist ekki hægt að segja að siðferði Laxdælu einkennist fyrst og fremst af einstaklingshyggju.

Miðað við framangreinda lýsingu fræðimanna á siðferði Íslendingasagna snýst pað öðru fremur um sæmd. Nota má pað pegar Bolli Bollason kemur heim eftir veru í útlöndum (kafli 77) til að varpa ljósi á pað kjarnaatriði sæmdarinnar að sjónarhorn annarra skiptir höfuðmáli. Í Laxdelu er pví lýst hvernig Bolli kemur heim búinn dýrgripum sem höfðingjar höfðu gefið honum. Jafnframt er pess getið að konur hafi dáð Bolla mjög og skart hans, venslamenn hans hafi tekið honum vel og að hann hafi orðið frægur af pessari ferð til útlanda. Forsenda sæmdar Bolla er ef til vill pað að hann hefur pað sem til parf til að öðrum lítist vel á hann. Sæmdin verður pó ekki staðreynd fyrir en aðrar manneskjur sýna aðdáun sína á honum. Рó að pað að sækjast eftir sæmd kunni að virðast heldur sjálfhverft fyrirbæri hefur sá einstaklingur sem pyrstir í sæmd pað fram yfir hinn fullkomlega sjálfhverfa einstakling að skilja sjónarhorn annarra og virða pað mikils. Dannig ættum við erfitt með að sjá fyrir okkur í ljósi hátternis peirra að Geirmundur gnýr og Porleikur Höskuldsson hafi sérstakan áhuga á pví að öđrum lítist vel á pá. 
Ef við skoðum nú aftur proskastig Gilligan má vera ljóst að sæmdarsiðferðið er á hærra stigi en eigingirni Geirmundar og Porleiks. Sæmdin tekur greinilega mið af öðrum manneskjum og innifelur pær í hinni siðferðilegu hugsun. Raunar er engin sæmd nema í samfélagi par sem einn virðir annan. Um leið virðist pessi áhersla á sæmd ekki vera ráðandi siðferðileg hugsun nú til dags. Almennt virðumst við vissulega virða sjónarhorn annarra en siðferði okkar í dag virðist pó vera komið lengra par sem pað tekur fleira fólk með í reikninginn en gert er almennt 1 Íslendingasögunum. Nægir par að nefna mikilvægi ættarinnar í Íslendingasögum og hvernig persónur taka sér skýra stöðu með peim hópi sem pær tilheyra. Detta birtist í virðingarleysi gagnvart peim sem ekki tilheyra pessum hópi, eins og pegar fram kemur að fórna má mannslífum húskarla fyrir sæmdina (kafli 47) og að mansal sé viðurkennt (kafli 12). Við hljótum pá að staðsetja sæmdarsiðferðið á öðru proskastiginu eða stigi fjölskylduhyggjunnar.

Hér má pó nefna tvennt sem viðbót við pessa niðurstöðu. Annars vegar er alls ekki útilokað að einhverjar persónur Íslendingasagna séu á priðja proskastiginu. Dæmi um petta gæti verið hvernig Ólafur konungur Tryggvason nálgast siðaskiptin í Noregi (kafli 40). Hann virðist sjá fyrir sér að í stóru samhengi sé kristni betri kostur en heiðni og almennt nálgast hann siðaskiptin frekar af varkárni og með sannfæringu en með heift og valdbeitingu. Detta breytir pó ekki meginniðurstöðunni um að pungamiðja sæmdarsiðferðisins sé á öðru proskastiginu. Hins vegar má velta fyrir sér hvernig pessar sögur geta haft svona mikið aðdráttarafl fyrir okkur og við getum sett okkur inn í pær ef pær eru á lægra proskastigi en samfélag okkar í dag. Um petta má segja að pegar einstaklingur proskast á hærra stig kastar hann ekki einfaldlega neðri proskastigum frá sér heldur eru pau áfram hluti af honum. Pannig getum við til að mynda samsamað okkur ungbörnum og áhugamálum peirra pó að við séum að mestu leyti vaxinn upp úr peim heimi. Með sama hætti getur siðferðileg togstreita í Íslendingasögum heillað okkur.

Nú, pegar gerð hefur verið grein fyrir siðferðilegri stöðu sæmdarsiðferðisins gagnvart almennu siðferði á okkar dögum, sjáum við að parna er nokkur munur. Og við sjáum jafnframt að pað getur ekki verið markmið að nemendur beinlínis tileinki sér pað siðferði sem finna má í İslendingasögum. Svo framarlega sem við getum pó nýtt okkur dygðaaðstæður til að hugsa út frá hlýtur samt að mega læra af sögunum. Eins og vikið hefur verið að áður er ekki nauðsynlegt að persónur Íslendingasagna séu færar um að yfirvega hluti siðferðilega til að við getum nýtt okkur sögurnar til yfirvegunar. Við skulum nú samt víkja að pví með hjálp proskalíkans Gilligan að reyna að átta okkur betur á stöðu hugsunar í heimi Íslendingasagna og hvernig hún sker sig frá siðferðilegri hugsun á priðja proskastiginu. Pær hugleiðingar ættu jafnframt að gera okkur ljóst hvaða proska við viljum að nemendur nái.

Fyrst má nefna að pó að flestar lýsingar í Íslendingasögum séu ytri lýsingar á háttalagi eru merki um pað í Laxdclu að persónur eigi sér innra líf, eins og áđur hefur verið nefnt (sbr. Frölich, 2000, bls. 85-156). Til merkis um tilfinningalíf persóna má til dæmis taka pað pegar pær roðna í andliti (sbr. kafla 21 og 42) en pað parf svo sem ekki að vera merki um siðferðilega yfirvegun. Einhvers konar slíka yfirvegun er pó að finna í Laxdæelu. Til að mynda er sagt að eftir fortölur Guðrúnar hafi Bolli miklað fyrir sér fjandskap sinn við Kjartan fóstbróður sinn og eftir að hann vó Kjartan er sagt að hann hafi strax iðrast verksins (kaflar 48 og 49). Petta verður varla skilið öðruvísi en sem einhvers konar innri togstreita sem hægt væri að túlka sem siðferðilega yfirvegun á einhverju stigi.

Ef við lítum aftur til proskalíkansins og hugum að peim möguleikum sem par eru á siðferðilegri hugsun sjáum við fyrst að fyllilega sjálfhverfur einstaklingur gengur einfaldlega út frá sjálfum sér og parf pví væntanlega lítið að hugleiða málin. Einstaklingur sem lifir í takt við fjölskylduhyggjuna hlýtur hins vegar að hafa flóknari valkosti. Persóna sem proskast hefur af fyrsta proskastiginu yfir á annað proskastigið getur pá bæði tengst fyrsta og öðru proskastiginu. Fyrir pann sem er veikur á svellinu geta pví komið upp hugleiðingar um hvort hann eigi að vera eigingjarn eða láta hollustuna við fjölskylduna ráða. Um leið getur einstaklingur átt í togstreitu eins og Bolli hér að framan. Pannig má líta svo á að togstreitan sé á milli mismunandi hópa venslamanna pví 
hann stendur frammi fyrir pví að fara að vilja eiginkonu sinnar Guðrúnar eða halda tryggð við Kjartan, uppeldisbróður sinn og frænda. Vel er hægt að líta á petta sem siðferðilega klemmu enda er einkenni slíkra klemma gjarnan talið pað að par stangist á mismunandi siðferðileg verðmæti par sem enginn kosturinn er beinlínis góður.

Að pessu sögðu virðast fæstar persónur Laxdæelu færar um að hugsa með óhlutbundnum hætti eins og peir purfa að gera sem eru á priðja proskastiginu. Sá sem er á pessu proskastigi hefur hæfileika til að gera sér almennar hugmyndir um alla menn og til pess parf óhlutbundna hugsun sem getur nád vítt og breitt og búið til almennar reglur sem taka til allra dæma (sbr. Gilligan, 1993, bls. 74). Jafnframt má segja að í pessu kristallist stökkið sem við viljum að nemendur taki í umfjöllun sinni um dygðir í Íslendingasögum, frá sérhagsmunum einstakra hópa til umhyggju fyrir hinni margbreytilegu heild. Og miðað við framansagt parf sá sem er á peim stað að fást við flóknara siðferðilegt landslag. Hann getur valið að vera eigingjarn, fylgja fjölskylduhyggjunni eða taka alla menn með í reikninginn eins og sá gerir sem til að mynda sér ranglætið í mansali jafnvel pó að sá sem á að selja líti öđruvísi út en hann sjálfur.

\section{Lokaorð}

Markmið greinarinnar var að skoða hvernig nota má Íslendingasögur til mannkostamenntunar. Fjallað hefur verið um mikilvægi dygða fyrir mannkostamenntun og jafnframt rætt um samband dygða og siðferðis par sem mannkostamenntun leggur einkum áherslu á siðferðilegar dygðir. pá hefur komið fram að hinn siðferðilegi veruleiki í Íslendingasögum einkennist af áherslu á sæmdarsiðferði. Með pví að nota stigskipt proskalíkan Gilligan hefur jafnframt verið reynt að koma auga á muninn á nútímasiðferði og pví siðferði sem viðgengst í Íslendingasögum og skilja hvers konar siðferðileg hugsun getur verið markmið í unglingakennslu. Jafnframt var fjallað um dygðaaðstæður í Íslendingasögum par sem ræða má um hvort viðbrögð persóna lýsi dygð eða ekki og hvort persónur hefðu átt að haga sér öđruvísi. Að pví gefnu að töluvert sé af dygðaaðstæðum í Íslendingasögum, að minnsta kosti ef marka má dæmin í Laxdaelu (sjá Róbert Jack, 2018a) verður ekki annað séð en að Íslendingasögur geti gagnast vel til dygðaumræðu. Val persónanna í sögunum getur verið okkur fóður til að skilja betur pá pætti sem taka parf með í reikninginn pegar siðferðileg ákvörðun er tekin.

\section{Virtues, ethics and moral development: Using Icelandic sagas in character education}

One possible approach to character education is through literature. The teacher looks for virtues in stories with her students and then these virtues are discussed to improve the students' understanding of virtue concepts and hopefully make them more aware of virtues in their own lives. In preparation for a research project where one of the Icelandic sagas, Laxdæla saga, was taught in this way to teenagers, some of the main conditions of the teaching had to be summarized. This article discusses the main themes that come into play here and puts the teaching of Icelandic sagas into the context of character education.

The article discusses the basic assumptions of character education that are important here; the connection between virtues and ethics, the concept of a virtue situation, research on ethics in the Icelandic sagas, whether ethics in the sagas means the same as in modernity, whether the sagas are suitable material for character education, whether the ethical reality found in them is different from ours, and, finally, what kind of moral thinking could be the aim of character education. 
The kind of character education used as the foundation for the research project is Aristotelian in nature as interpreted by the members of The Jubilee Centre for Character \& Virtues at the University of Birmingham (cf. Kristján Kristjánsson, 2015). The discussion of character education deals with the importance it places on virtue, its emphasis on moral virtue and the general connection of virtues and ethics. It is suggested that this kind of character education may embrace a broader understanding of moral virtue than is commonly accepted. It is, however, argued that this only has a minor, if any, effect on how character education is practised.

The concept of a virtue situation is introduced. This refers to a situation, in which a character in a story finds herself, which is well suited to evaluating the character's virtues. This may be a relatively mundane situation or one which is charged with moral tension. It is argued, furthermore, that such situations are easily found in the Icelandic sagas, which makes it a relatively simple task to discuss virtuous action in the context of the sagas.

The main ideas scholars have had about ethics in the saga literature are introduced. This is important for two reasons. Firstly, virtues are strongly connected to ethical views. Since most of the virtues covered in character education are moral virtues, much can be learnt about a character's opinions of virtues from her ethical stance. Secondly, it would appear that the kind of ethics that dominates the saga world differs from the ethics prevalent in the modern Western world. When discussing why the characters in the sagas behaved in the way they do it helps to have an understanding of the differences in values between them and us.

To throw light on the difference between saga ethics and modern ethics, Gilligan's (1993) model of moral development is used. In this context some criticisms of Kohlberg and Gilligan are discussed and it is explained that neither the content of Gilligan's nor Kohlberg's model is used here, but rather the basic point of view that each stage of development entails. Thus we can gain a rough understanding of how characters in the sagas generally think differently about ethical matters than people today.

The developmental model further helps us answer the question as to whether the sagas are suitable material for character education, given that the ethical reality found in them is different from ours, as well as showing us what kind of moral thinking could be the aim of character education.

Keywords: character education, teaching literature, Icelandic sagas, virtue, moral development, ethics.

\section{Um höfundinn}

Róbert Jack (robjack@hi.is) er nýdoktor og aðjunkt við Menntavísindasvið Háskóla Íslands. Hann hefur m.a. birt skrif um mannlegan proska, heimspekilega samræðu og pjónandi forystu.

\section{About the author}

Róbert Jack (robjack@hi.is) is a postdoctoral researcher and adjunct lecturer at the School of Education, University of Iceland. He has among other things published on human development, philosophical dialogue, and servant leadership. 
Dessi grein er hluti af rannsóknarverkefni sem var unnið með styrk úr Rannsóknarsjóði Íslands (nr. 163230-051) og pakka ég sjóðnum fyrir stuðninginn. Ég pakka einnig Atla Harðarsyni, Ólafi Páli Jónssyni, Dóru Björgu Sigurðardóttur, kennurum og öðrum peim sem komu að verkefninu fyrir samstarfið og gagnlegar umræður um efnið. Loks vil ég pakka ritrýnum fyrir gagnlegar ábendingar.

\section{Heimildir}

Arthur, J., Kristjánsson, K., Harrison, T., Sanderse, W. og Wright, D. (2017). Teaching character and virtue in schools. New York: Routledge.

Atli Harðarson. (2018). Ógæfa Bolla Dorleikssonar: Hugleiðing um hvernig Laxdæla saga leggur spurningar fyrir lesanda sinn en svarar peim ekki. Netla - veftímarit um uppeldi og menntun. Sérrit 2018 - Bókmenntir, listir og grunnpattir menntunar. Menntavísindasvið Háskóla Íslands. Sótt af http://netla.hi.is/serrit/2018/ bokmenntir_listir_menntun/02.pdf

Atli Harðarson, Ólafur Páll Jónsson, Róbert Jack, Póra Björg Sigurðardóttir og Sigrún Sif Jóelsdóttir. (2018) Laxdæla saga og orðaforði um siðferði. Netla - veftímarit um uppeldi og menntun. Sérrit 2018 - Bókmenntir, listir og grunnpattir menntunar. Menntavísindasvið Háskóla Íslands. Sótt af http://netla.hi.is/serrit/2018/ bokmenntir_listir_menntun/01.pdf

Frölich, D. (2000). Ehre und Liebe: Schichten des Erzählens in der Laxdela saga. Frankfurt am Main: Peter Lang.

Gilligan, C. (1993). In a different voice: Psychological theory and women's development. London: Harvard University Press.

Íslensk orðabók. (2003). Reykjavík: Edda.

Kristján Kristjánsson. (1998). Liberating moral traditions: Saga morality and Aristotle's megalopsychia. Ethical Theory and Moral Practice, 1(4), 397-422. doi:10.1023/A:1009990801822

Kristján Kristjánsson. (2002). Mannkostir. Reykjavík: Háskólaútgáfan.

Kristján Kristjánsson. (2010). The self and its emotions. New York: Cambridge University Press.

Kristján Kristjánsson. (2015). Aristotelian character education. London: Routledge.

Laxdala saga (endursögn Gunnars Karlssonar). (2017). Kópavogur: Menntamálastofnun.

MacIntyre, A. (2007). After virtue: A study in moral theory (3. útgáfa). Notre Dame: University of Notre Dame Press.

McLaughlin, T. H. og Halstead, M. (1999). Education in character and virtue. Í J. M. Halstead og T. H. McLaughlin (ritstjórar), Education in morality (bls. 132-163). London: Routledge.

Meulengracht Sørensen, P. (1995). Fortalling og are: Studier i islandingesagaerne. Oslo: Universitetsforlaget.

Morris, I. (2015). Teaching happiness and well-being in schools (2. útgáfa). London: Bloomsbury.

Ólafur Páll Jónsson. (2018). Laxdæla sem fóður fyrir gagnrýna hugsun. Netla - veftímarit um uppeldi og menntun. Sérrit 2018 - Bókmenntir, listir og grunnpettir menntunar. Menntavísindasvið Háskóla Íslands. Sótt af http:// netla.hi.is/serrit/2018/bokmenntir_listir_menntun/06.pdf

Róbert Jack. (2018a). Dygðirnar í Laxdæla sögu: Efniviður fyrir mannkostamenntun. Netla - veftímarit um uppeldi og menntun. Sérrit 2018 - Bókmenntir, listir og grunnpattir menntunar. Menntavísindasvið Háskóla Íslands. Sótt af http://netla.hi.is/serrit/2018/bokmenntir_listir_menntun/10.pdf

Róbert Jack. (2018b). Laxdcela saga: Dygðakennsla. Sótt af https://klb.mms.is/ - /laxdaela/dyga-kennsla-robert-jack/?_k=p1xwwu

Sanderse, W. (2012). Character education: A neo-Aristotelian approach to the philosophy, psychology and education of virtue. Delft: Eburon.

Sanderse, W. (2015). An Aristotelian model of moral development. Journal of Philosophy of Education, 49(3), 382-398. doi:10.1111/1467-9752.12109

Sigurður Nordal. (1942). Íslenzk menning. Reykjavík: Mál og menning. 
Steblin-Kamenskij, M. I. (1981). Heimur Íslendingasagna (Helgi Haraldsson pýddi). Reykjavík: Iðunn.

Svavar Hrafn Svavarsson. (2009). Honour and shame. Gripla, 20, 241-256.

Samdarmenn: Um heiður á pjóðveldisöld. (2001). Reykjavík: Hugvísindastofnun Háskóla Íslands.

The Jubilee Centre for Character \& Virtues. (2014). Knightly virtues: Enhancing virtue literacy through stories. Sótt af https://www.jubileecentre.ac.uk/userfiles/jubileecentre/pdf/KVPDF/KnightlyVirtuesReport.pdf

The Jubilee Centre for Character \& Virtues. (2017). A framework for character education in schools. Sótt af https://uobschool.org.uk/wp-content/uploads/2017/08/Framework-for-Character-Education-2017-Jubilee-Centre.pdf

Torfi H. Tulinius. (2001). Virðing í flóknu samfélagi. Í Scemdarmenn: Um heiður á pjóðveldisöld (bls. 57-89). Reykjavík: Hugvísindastofnun Háskóla Íslands.

Van den Toorn, M. C. (1955). Ethics and moral in Icelandic saga literature. Assen:Van Gorcum.

Vilhjálmur Árnason. (1985). Saga og siðferði: Hugleiðingar um túlkun á siðfræði Íslendingasagna. Tímarit Máls og menningar, 46(1), 21-37.

Vilhjálmur Árnason. (1991). Morality and social structure in the Icelandic sagas. Journal of English and Germanic Philology, 90(2), 157-174.

Wilber, K. (2006). Integral spirituality: A startling new role for religion in the modern and postmodern world. Boston: Integral Books.

Dóra Björg Sigurðardóttir. (2018). Siðfræði í bókmenntakennslu. Netla - veftímarit um uppeldi og menntun. Sérrit 2018 - Bókmenntir, listir og grunnpattir menntunar. Menntavísindasvið Háskóla Íslands. Sótt af http:// netla.hi.is/serrit/2018/bokmenntir_listir_menntun/11.pdf

Róbert Jack. (2018)

Dygðir, siðferði og siðferðisproski: Að nota Íslendingasögur til mannkostamenntunar.

Netla - veftímarit um uppeldi og menntun. Sérrit 2018 - Bókmenntir, listir og grunnpættir menntunar.

Menntavísindasvið Háskóla Íslands.

Sótt af http://netla.hi.is/serrit/2018/bokmenntir_listir_menntun/09.pdf

https://doi.org/10.24270/serritnetla.2019.22 